Pål Kolstø. The Demonized Double: The Image of Lev Tolstoi in Russian Orthodox Polemics.

Slavic Review, 2006, 65(2), pages 304-324

This article is published in

Slavic Review, 2006, Volume 65, Issue 2, Pages 304-324

http://www.slavicreview.uiuc.edu/indexes/vol65/

Published in DUO with permission from American Association for the Advancement of Slavic Studies.

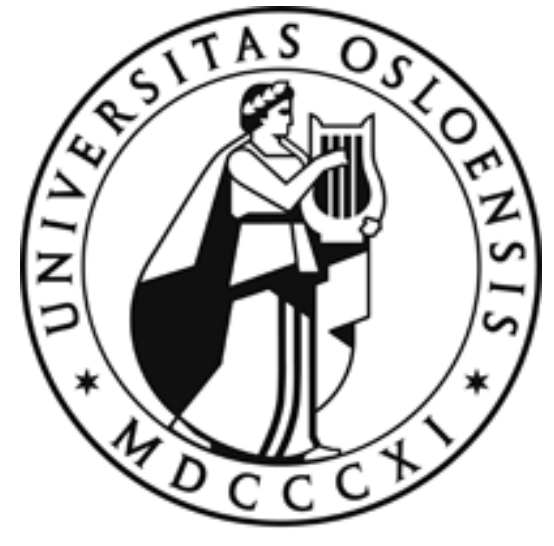




\section{The demonized double: The image of Lev Tolstoi in Russian}

\section{Orthodox Polemics}

At the end of the $19^{\text {th }}$ and the beginning of the $20^{\text {th }}$ century, the Russian Orthodox Church was deeply concerned with Lev Tolstoi's religious teaching. The church dignitaries regarded Tolstoi as a more formidable adversary than other church critics and heretical preachers in contemporary Russia. ${ }^{1}$ There were a number of reasons for this, one being Tolstoi's world fame as a writer. He had both a brilliant pen and a well-disposed audience for his pernicious message and could therefore reach out to far more people than any simple-minded sectarian. As one Orthodox writer observed,

L. Tolstoi stands at the center of attention for the critics as well as for the general public. His moral and social ideas are talked about by everyone: In the drawing rooms, in the learned societies, in the literary circles and among the youth. They are written about in the popular press as well as in the pages of the serious journals, the secular and the theological alike. ${ }^{2}$

This description was hardly an exaggeration. The public debate spurred by Tolstoi's religious and social writings is an important part of Russia's intellectual history in the last decades of the 
$19^{\text {th }}$ century and the first of the $20^{\text {th }}$. Part of this vast debate has been examined by the Tolstoi scholarship. Erwin Oberländer has traced the reactions to Tolstoianism among Russian revolutionaries while Peter Ulf Møller has documented the fierce debate unleashed by the publication of Tolstoi's succés de scandale, The Kreutzer Sonata. ${ }^{3}$ As the above quotation illustrates, also Orthodox believers contributed massively to the Tolstoi debate. Hundreds of articles and dozens of books and booklets were written about the new prophet at Iasnaia Poliana by people who wanted to defend the position of the church against his attacks. ${ }^{4}$ While much of this literature was run-of-the-mill stuff of no lasting significance, also many of the finest Orthodox thinkers of the time contributed, including such luminaries as Vladimir Solov'ev (1853-1900), Sergei Bulgakov (1871-1944), and bishop Antonii (Khrapovitskii, 1863-1936). Indeed, it seems that no issue had ever agitated the minds and pens of Orthodox believers as much as Tolstoianism did. Not only priests and church officials, but also a great number of laymen (and a few laywomen) joined the fray. A further point is that many of the antiTolstoian Orthodox pamphlets and brochures were surprisingly published outside the capitals, in provincial cities such as Kazan', Kharkov, Saratov, and Riazan' The Tolstoi case created a nationwide Russian Orthodox writing public.

Tolstoi scholars have paid little if any attention to the Orthodox contributions to the Tolstoi debate. ${ }^{5}$ In so far as they have shown any interest at all in the relationship of the Russian Orthodox Church to Tolstoi they have tended to focus almost exclusively on the public circular (poslanie) against Tolstoi that was promulgated by the Holy Synod in February 1901-usually referred to as his "excommunication"- as if that document expressed the attitudes of all Russian Orthodox believers. As this article will show, such was far from being the case. Many 
Orthodox writings on Tolstoi and Tolstoianism contradicted each other, and occasionally also the official position of the Church. Often the various authors present Tolstoi in so different ways that one wonders sometimes if they were all really writing about the same person. Most Orthodox writers who defended viewpoints in conflict with the poslanie expressed more moderate stances than the church leadership, but some represented more uncompromising, strident positions. These writings then, taken together, bear witness not only to the breadth and vitality of Orthodox public opinion, but also to its strong and increasing polarization. ${ }^{6}$

Most Orthodox anti-Tolstoian tracts and articles discussed particular aspects of Tolstoi's teaching such as his aesthetics, his interpretation of the Gospels, or the point of one of his novels or short stories. Each time a new book or article emanated from Tolstoi's study chances were that one or more Orthodox rebuttals would instantly be published to refute it. For reasons of space this specialized literature can not be discussed in this article. Instead I will limit myself to those writings that took a bird's eye view of Tolstoianism, that tried to present a comprehensive, synthetic picture of the Tolstoi phenomenon. My presentation of these works will be organized according to one criterion: to what degree did they see Tolstoianism as being similar/dissimilar to Orthodoxy?

The two most radical stances dividing Orthodox believers on the Tolstoian issue may be dubbed "Tolstoi as Orthodox double" and "Tolstoi as demon." According to the first group of writers, Tolstoi was certainly not a true Orthodox believer- he vehemently denounced most Orthodox tenets - but many of his philosophical notions were nevertheless remarkably congenial to the teachings of the Church (or what these writers felt ought to have been the teaching of the 
Church). Some pointed to his emphasis on personal self-perfection and his preaching of poverty and asceticism, ideas which, they felt, brought him close to the message of the Orthodox monks. Others praised his social gospel and his message of non-violence as genuine Orthodox concerns. Some went as far as to say that Tolstoi, on a particular issue, expressed the Orthodox position in a clearer and truer form than the contemporary Russian Church itself did. This group of writers presented Tolstoi not as a threat to the Christian faith but as a positive figure with a wholesome influence on Russian society. While not a Christian himself, he had prepared the ground for a religious revival. At a time when the Russian public was sinking ever deeper into the quagmire of materialism, Tolstoi had proclaimed that the really important matters in life were spiritual. He had asked the right questions and pointed in the right direction, but, unfortunately, gave the wrong answers. Luckily, the Orthodox Church could provide the correct answers, and could therefore reap the harvest that Tolstoi had sown. This position was eloquently summed up by bishop Antonii (Khrapovitskii) and the philosopher Sergei Bulgakov. Both pointed out that some early church fathers had regarded virtuous pagan sages like Plato and Virgil as paidagogoi eis Christon, that is, good people who, while not Christians themselves, nevertheless guided others to Christ. This same function, they believed, could aptly be said to describe Tolstoi's relation to the church in the presently rather irreverent Russian society. $^{7}$

Other Orthodox writers agreed that Tolstoi's message often bore an uncanny resemblance to Orthodox teaching, but insisted in addition that whatever might be found in his beliefs of truth and virtue he had purloined from the Church. Tolstoi was a plagiarist who had "stolen the pearl of the Gospel," he was "a peddler of contraband." 8 The true or seemingly true ideas in his 
teachings had all been taken out of context and could therefore no longer be recognized as genuinely Orthodox. The task of the Orthodox apologist, therefore, was to expose this twofold nature by "separating the wheat from the tares, and the grain of truth from the glitter of tinsel.", One priest admitted that Tolstoi's teachings were marked by "high moral beauty," but hastened to add that there was a "but":

This "but," gentlemen, is extraordinarily important: this entire beauty Tolstoy has stolen from us, from the Christian church. All of it is lifted from the Gospel! Tolstoi plundered Christ, he robbed Him. Then he threw Christ aside in order to shine for the world with the treasures he had taken! ${ }^{10}$

Most Orthodox writers, however, saw Tolstoianism neither as a model nor as Orthodox plagiarism, but as the radical negation of everything the church stood for. Tolstoi was the sworn enemy of Christ and the church (no distinction was drawn between the two), a godless blasphemer, a liar and depraver of youth, the devil's envoy, a demon. An image often conjured up was Tolstoi as the Antichrist, the ultimate adversary of Christ at the end of time. The New Testament tells us little about this ominous eschatological figure but the very vagueness of the biblical information on the Antichrist made him even more amenable to fanciful interpretations. In Russian history a number of persons had been identified as Antichrist, without the end manifesting itself. ${ }^{11}$ Now, many believed, Tolstoi fit the bill better than anyone else before him. A weaker version of the same conjecture claimed that Tolstoi was not Antichrist himself, but his forerunner or standard-bearer. 
What exactly qualified Tolstoi for this most sinister role? Answers vary, but to some, including one of the most profound Russian thinkers in the $19^{\text {th }}$ century, Vladimir Solov'ev, it was precisely the features that made others see Tolstoi as an Orthodox double that led them to this conclusion. The Antichrist will manage to lead the faithful astray precisely because he will seem to them to imitate Christ himself. Antichrist is the demon double. This was the basis on which the most extreme positions in the Orthodox debate on Tolstoi and Tolstoianism converged and closed the circle.

\section{Tolstoi-the Orthodox double}

In their polemics minted for each other, both the Holy Synod and Tolstoi underscored the significant differences that separated their belief systems. In the 1901 poslanie the Synod accused Tolstoi of "overthrowing all dogmas of the Orthodox Church with the zeal of a fanatic." He denied the Trinity and God as creator and sustainer of the universe; he rejected faith in Christ as redeemer and savior of mankind, resurrection from the dead, the virgin conception, life after death, and eternal retribution. "He abuses all the most sacred objects of faith of the Orthodox people and mocks even the greatest of all sacraments, the Eucharist." ${ }^{, 12}$ In his Reply to the Synod Tolstoi did not deny any of this. While he insisted he was not a blasphemer and that faith in God was vitally important to him, he admitted that he indeed regarded the trinity as a fable, the dogma of virgin birth as blasphemous, and the sacraments as "base and crude." ${ }^{\prime 13}$ Since both sides to this dispute agreed on all major points the case would seem to be closed. 
Even so, there remained in Tolstoi's philosophy a clear remnant of Orthodox thinking. ${ }^{14}$ It could hardly be otherwise. Tolstoi had been exposed to the Christian faith in its Orthodox version, and when he attacked "the church", he clearly had in mind first and foremost the Russian Orthodox Church, the one he knew best. In his close clinch with Orthodoxy a specifically Orthodox way of thinking about life and the world rubbed off on him. ${ }^{15}$ Charles Lock has claimed that "Tolstoi is most Orthodox, and prophetically so, in his attacks on the established Orthodox Church." "16 This assessment, I believe, is very accurate.

There is no denying that Tolstoi broke decisively with the church on fundamental points, and the stark anti-Orthodox vehemence of his message should not be glossed over. ${ }^{17}$ But that does not prevent us from unearthing lines of influence. What will concern us here is that several contemporary Russian Orthodox authors detected vestiges of Orthodox thinking in parts of Tolstoi’s teaching.

Some remarkably positive assessments of Tolstoi and Tolstoianism can be found among the radical lower clergy in St. Petersburg. ${ }^{18}$ Sympathetic sentiments were expressed, for instance, in the journal Otdykh Khristianina, the organ of the religious temperance society "The Aleksander Nevskii brotherhood." Several contributors to this journal wrote articles about Tolstoi, mostly in a rather favorable vein. ${ }^{19}$

A sort of a summary statement on Tolstoi from this group of socially concerned urban clergy was written in 1916 by the priest Stefan Ostroumov under the symptomatic heading "The positive significance of L.N. Tolstoi's religious and moral teaching. ${ }^{, 20}$ Most Orthodox writers, 
Ostroumov maintained, had given a one-sided version of Tolstoianism. Even on those points where Tolstoi's teaching hardly deviated from the doctrine of the church, they had diligently underscored the minor differences that could be found. These Orthodox scribes had bypassed in silence Tolstoi's ideas on fasting, self-sacrifice, chastity, and so on, points that were close to an Orthodox understanding of life. Instead, their gaze had been fixed on his rejection of the State and Christian supranaturalism. For this reason they had failed to notice that Tolstoi's writings did not have a detrimental effect on all readers. Some people had in fact been persuaded to return to the true faith via their reading of Tolstoi.

Ostroumov found precedence for his approach to Tolstoianism in the hermeneutics of the Church Fathers. The first Christian apologetics had read the works of heathen philosophers such as Plato and Aristotle with an open mind, and had concluded that many of the profound ideas therein conformed to a remarkable degree with the truths of the Gospel. In their reading of pre-Christian literature early Church Fathers had been guided by "the nectar principle": A bee can collect nectar from poisonous flowers as well as from beneficial ones. ${ }^{21}$

The Russian Church leadership was clearly uncomfortable with such liberal interpretations of Tolstoianism, but most of the time they tried to ignore them. Only on two occasions, it seems, did they feel the line had been crossed and an example should be set. The first incident involved the radical St. Petersburg priest Grigorii Petrov, who at a meeting in the St. Petersburg Religious-Philosophical Society in February 1901 declared that Tolstoi performed the same role for contemporary Russian society as Virgil had done for Dante. ${ }^{22}$ Tolstoi led spiritually astray Russians through fire and purgatory to the gates of heaven. Petrov's superior, Metropolitan 
Antonii (Vadkovskii) of St. Petersburg and Ladoga, was furious and summoned the errant priest to his office. Petrov's explanations did not assuage him. Already the next day Antonii took the initiative to have promulgated the famous poslanie with a public warning against Tolstoi, in an attempt to prevent such flattering descriptions of Tolstoi from circulating among the faithful. ${ }^{23}$

The other time when disciplinary action was taken against a radical priest with pro-Tolstoi sympathies occurred ten years later, in 1911, once again prompted by a speech within the St. Petersburg Religious-Philosophical Society. Professor of patristics at Kiev Theological Academy, Vasilii Ekzempliarskii, had been invited to talk on the intellectual relationship between the recently deceased writer and St. John Chrysostom, one of the most popular saints of the Eastern Church. This stern and ascetic $4^{\text {th }}$-century Byzantine patriarch was famous not least for having lashed out from the pulpit of his cathedral church against luxury and social injustice. When the Constantinople upper classes decided they could take no more of this, the patriarch was deprived of his office and sent into internal exile. Ekzempliarskii claimed a remarkable congruence of ideas between the Greek Church Father and the late Russian thinker, as exemplified in

their understanding of private property rights, in particular the notion that land should not be privately owned. Furthermore, both reject oath-taking in the life of a Christian, and agree in regarding poverty as a positive good. Both think that city life is unnatural; emphasize the significance of physical labor; regard the life of the Christian on earth as a pilgrimage, and so on. ${ }^{24}$ 
Ekzempliarskii also claimed that all the most important Church Fathers had been in agreement with Chrysostom, thus implying that Tolstoi's social message basically coincided with the social teachings of true Orthodoxy. Even so, Tolstoi had not found Christ's true message in the church. The main blame for this Ekzempliarskii placed at the door of Russian theology. On important points it had deviated from the social teaching of the universal church.

Our Russian theological thought has besmirched itself by attempts to prove that the teachings of the Gospel sanction serfdom and corporal punishment, the opulence of the rich, capital punishment, coercive measures against peoples' conscience, and many, many other things... ${ }^{25}$

Whenever Russian theologians attacked Tolstoi's teachings, they therefore contributed to the cementing of a commonly accepted but misconceived understanding of what the Church really teaches on social matters, Ekzempliarskii concluded.

This broadside was more than the Russian church establishment could endure. Ekzempliarskii was accused of "anti-Orthodox activity" and given a dishonorable discharge from his position at the Kiev Academy. He was refused the right of defense and chose instead to present his case before the Russian public. In his published apology he emphasized that it had not been his intention to elevate Tolstoi to the status as a new doctor of the church. The professor fully realized that Tolstoi's religious ideas placed him well beyond the pale of the Christian community. Even so, Ekzempliarskii insisted that Tolstoi's teaching was a path "to the promised land.” Indeed, “after St. John Chrysostom, not one of our moral theologians has 
explained the significance of the Gospel message for this life in such a lucid, determined, and straight-forward way as late L. Tolstoi did. ${ }^{26}$ Thus, Tolstoi was not a fake look-alike, but closer to the original that than many who pretended to be Orthodox guardians of truth.

The Ekzempliarskii case developed into a scandal and widened the growing schism between the liberal and reactionary camps in the Russian church. Sergei Bulgakov was one prominent Russian intellectual who publicly defended the expelled professor. It was most peculiar, Bulgakov felt, that the church leadership should suddenly exhibit such a zeal for the correct teaching when they for such a long time had abetted the antics of the religious charlatan Grigorii Rasputin. $^{27}$

It should be noted that not only fringe radicals but also some centrally placed theologians acknowledged the spiritual and intellectual affinities between Tolstoianism and Orthodoxy. This was true in particular of Metropolitan Antonii (Khrapovitskii), one of the most influential leaders of the Russian church at the turn of the century. A political reactionary, Khrapovitskii emigrated from Russia under the Civil War and ended up as the first leader of the pro-tsarist and fervently anti-Bolshevik Russian Orthodox Church Abroad (Russkaia pravoslavnaia tserkov'za rubezhem).

Antonii had shown great interest in Tolstoi's thinking over a lengthy period. He wrote seven books and articles on various aspects of Tolstoianism and visited Iasnaia Poliana in 1892. Already in 1889 Antonii concluded that while Tolstoi's philosophy on many points clearly deviated significantly from church doctrine, on other points Tolstoi "unconsciously repeats the 
teaching of the church." ${ }^{28}$ This viewpoint Antonii elaborated on in a lecture he delivered 22 November 1910, shortly after Tolstoi's death, under the title "How Influence from Orthodoxy is Reflected in Count L.N. Tolstoi’s Later Works." ${ }^{29}$ In this lecture Antonii characterized Tolstoi as a raskol'nik, a schismatic, a term normally reserved for Russian dissidents with Orthodox roots. It was no slip of the tongue. The spiritual relationship between Orthodoxy and Tolstoi's thinking went deep, Antonii asserted, much deeper, in fact, than Tolstoi himself had been aware of. An important reason why Tolstoi's teaching had had such remarkable success in Russia was the fact that he built upon traditional Russian ideas, the metropolitan believed. One such idea was the importance of individual self-perfection, another that every person has to be reborn, a third that human nature, deep down, is divine.

The greatest similarities between Tolstoi's teachings and the doctrine of the Orthodox church Khrapovitskii found in the area of asceticism. Tolstoi professed and, up to a point, also practiced in his own life the three basic monastic vows - chastity, poverty, and abstinence from meat. "In this way he approached the standards of monastic life. The monks teach that denial of pleasure is precisely what kills the principle of self-love in us and enhances the holy love of God and our neighbor." ${ }^{, 30}$ Thus, according to this prelate, Tolstoi had exhorted his followers not only to lead the life of a Christian, but to do so in the most strict and sublime form - by following the calling of the monastics.

Russian theologians like Ostroumov, Ekzempliarskii, and Khrapovitskii who dug out Orthodoxy-inspired nuggets from the teachings of Tolstoi, did so for a purpose. They were dismayed by certain aspects of Russian society, and in an attempt to rectify the situation they 
held up Tolstoi as a mirror to chastise their contemporaries. Stefan Ostroumov admitted that to children and the common people Tolstoi's teachings could only be harmful as they might undermine their simple faith. Not so for adults of the educated classes. "Tolstoi's religious teaching is wholesome for those who have lost the holy faith as well as for conscious Orthodox believers, as it points out grave abnormalities in society, in the state, the church, the family and in our private lives." ${ }^{, 31}$ For his part, Metropolitan Antonii asked rhetorically: "We upbraid Tolstoi for having distorted Orthodoxy, but have we in our daily life shown him the truth of Orthodoxy?" 32 The godless lifestyle of contemporary Orthodox Christians made a mockery of the faith, and provided fertile soil for heretics like Tolstoi. It was easy to tear Tolstoianism apart theoretically, but it would continue to exert a strong appeal as long as true Orthodoxy was being practiced only by a few monks and peasants, the bishop declared. ${ }^{33}$

\section{Tolstoi Demonized}

The self-critical approach toward Tolstoi and Tolstoianism that permeates the writings presented above was only one of several currents flowing within the Russian church, and not the most influential one either. A more common reaction was to denounce Tolstoi and his teaching partout, with no caveats, qualifications, or nuances. He was a deceiver, an apostate, and a blasphemer. Did Tolstoi give spiritual guidance like a starets? If so, then he was an "impious (nechestivyi) starets." ${ }^{34}$ Did he want to be a prophet? In that case he was a prophet of Baal. $^{35}$ 
Many irate Orthodox writers who wanted to drag Tolstoi through the mud sought in the Scriptures for suitable epithets. Some of the most obvious biblical metaphors were those that used the word "lion" since they could be linked directly to Tolstoi's given name. ${ }^{36}$ Tolstoi was “a roaring lion, seeking someone to devour," a clear allusion to the devil (see 1 Peter 5,8). ${ }^{37}$ Another drastic metaphor applied remarkably often for Tolstoi was "Antichrist." Some authors used it as nothing but an insult, indicating that they were running out of invectives. ${ }^{38}$ In the New Testament the word Antichrist is used both as a proper and a common noun, and in some modern European languages, including Russian, it has retained this ambiguity. ${ }^{39}$ This circumstance several Orthodox writers made full use of, for instance Mikhail Sopots'ko, a former Tolstoian-turned-Orthodox lay preacher. Sopots'ko warned his readers about his former mentor, whom he now described as an "undisguised antichrist." Sopots'ko went on to declare, surprisingly, that "even this expression, in our view, is too mild." ${ }^{, 40}$ While for some, then, this most terrible of names seemed to be loosing its power to shock, for most contemporary Russian Orthodox believers the word Antichrist still had the power to send cold shivers down their spines. The vast majority of those who described Tolstoi as a, or the, Antichrist, clearly wanted to capitalize on its apocalyptic connotations. ${ }^{41}$

When Tolstoi organized a relief center for the destitute during the 1890-92 famine many peasants did not dare to accept the help they were proffered: they had been told that the great writer was the Antichrist. "Under the impetus of the priests, a whole folklore grew up in the region [of Begichevka] about Tolstoi as Antichrist," writes Ernest Simmons. ${ }^{42}$ Written evidence of this rumor, however, can be found only in the latter part of the 1890s. 
One devotional journal, Dushepoleznoe chtenie, repeatedly presented Tolstoy to its readers as the Antichrist or a precursor of Antichrist. ${ }^{43}$ Thus, for instance, in 1899 the journal printed an anonymous letter from a reader who claimed to have incontrovertible mathematical proof that Tolstoy was Antichrist. This he had arrived at by employing a mysticism of numbers. All characters in the Church Slavonic alphabet are assigned with a numerical value, and by substituting all letters in Tolstoi's name with their Church Slavonic number values this reader achieved some startling results. ${ }^{44}$

\begin{tabular}{ll}
$\mathrm{T}=300$ & $\mathrm{~L}=30$ \\
$\mathrm{O}=70$ & $\mathrm{E}=5$ \\
$\mathrm{~L}=30$ & $\mathrm{~V}=2$ \\
$\mathrm{~S}=200$ & \\
$\mathrm{~T}=300$ & $\mathrm{~N}=50$ \\
$\mathrm{O}=70$ & $\mathrm{I}=8$ \\
$\underline{\mathrm{J}=10}$ & $\mathrm{~K}=20$ \\
$\underline{\underline{=980}}$ & $\mathrm{O}=70$ \\
& $\mathrm{~L}=30$ \\
& $\mathrm{~A}=1$ \\
& $\mathrm{I}=8$ \\
& $\underline{\mathrm{Ch}=90}$ \\
& $\underline{\underline{-314}}$ \\
\hline &
\end{tabular}


The anonymous mathematician-cum-mystic first added the values of all characters in Tolstoi's first name and patronymic, next, he went through the same procedure separately with the numerical value of the characters in Tolstoi's last name. Finally, the latter sum was subtracted from the former. The reason for this final calculation, it was explained, was Tolstoi's apostasy: Since he had left the church one had to take away from him the names he had been given by the church. $^{45}$ The bottom line gave 666 , the number of the Beast in the Apocalypse.

The editors of Dushepoleznoe chtenie indignantly rejected claims set forth in the secular Russian press that they had identified Tolstoi as Antichrist. ${ }^{46}$ An editorial note explained that if simple-minded Russians did so, Tolstoi's followers were themselves to be blamed. The Tolstoians allegedly hailed their ringleader as "a perfected Christ" and this blasphemous epithet had prompted some Orthodox believers to see Tolstoi as a harbinger of the end of times, the journal asserted. ${ }^{47}$

While denying any authorship of the Antichrist legend, the editors of Dushepoleznoe chtenie nevertheless kept up interest in it by reprinting the number-juggling with Tolstoi's name two years later. ${ }^{48}$ The journal also continued to inform its readers about new religious tracts that presented Tolstoi as Antichrist or as a person in the Antichrist's entourage. In particular, they showed great interest in the apocalyptic and anti-Tolstoian writings of father John of Kronstadt. $^{49}$

John of Kronstadt (Sergiev, 1829-1908) was one of the most remarkable Russian church figures in the last decades of the Tsarist empire. Most of his adult life he worked as parish priest on 
the island of Kronstadt in the Gulf of Finland. He traveled all over Russia, and wherever he went, he attracted large crowds of the faithful to his outdoor services. John allegedly also possessed healing powers. Politically he was an ardent supporter of tsardom, and after 1905 he became an honorary member of several Black Hundred organizations. ${ }^{50}$ While father John was worshipped by his followers he was a hate figure for the radical Russian intelligentsia.

The anti-Tolstoian writings of John of Kronstadt are not noted for their profundity, but in the history of ideas they nevertheless occupy an important place as they reached a wider audience than similar Orthodox writings. While some anti-Tolstoian pamphlets had a print-run of no more than a couple of hundred copies, John's writings were issued and reissued by several publishers, reaching up to 40,000 copies at each printing.

In his diverse writings father John repeatedly lambasted Tolstoi and his teaching, and the scattered anti-Tolstoian passages in his books and pamphlets were collected and issued separately by his devotees. ${ }^{51}$ In one of these brochures Tolstoi's teaching was declared to be a systematic and consistent lie. On one and the same page the words "lie," "lying" and "mendacious" appeared no less than fifteen times. Gradually the reader realizes that it is not any ordinary lie John is referring to, but the great Lie at the End of Time (cf. 2 Thess 2$).{ }^{52}$ With reference to 1 John 2, 22 father John exclaimed: "Look at these modern, impudent apostates, Tolstoi and his followers: they are the true antichrists. They are liars, as John the Apostle says: Who is the liar, but he who denies that Jesus is the Christ?"53 The argument was intriguingly simple: A: Those who deny that Jesus is Christ, are liars and antichrists. B: Tolstoi denies that Jesus is Christ. C: Tolstoi is (an) antichrist. 
In another passage father John identified Tolstoi as the dragon mentioned in the Book of Revelation, 12, $4 .^{54}$ Raising the stakes further still, John insisted that Tolstoi's blasphemy was worse that the devil's. The devil, however evil, believes in and fears God. ${ }^{55}$ Tolstoi, for his part, did not believe in the Son of God and ridiculed the truth of the Gospel. "Thus you shall know the godless by their fruits. When he abuses the entire Christian congregation, you will know who he is. This is antichrist - this is the beast that ascends from the abyss with ten horns (Revelation 11,7 and Revelation 13,1).,56

Some admirers of the Kronstadt priest organized semi-monastic fraternities in which they tried to live up to his stern instruction. The members of these fraternities were popularly referred to as the Ioannites, and many contemporary observers regarded them as sectarians, a label they themselves strongly rejected. They took Communion on a weekly basis and wanted nothing more than to be true and fervent Orthodox believers. The Ioannites, however, nourished a deep sense of skepticism toward the official Russian church, which they regarded as ossified and uncharitable. While some Russian theologians saw no reason to doubt their orthodoxy, ${ }^{57}$ their great idol, John of Kronstadt himself condemned them publicly. ${ }^{58}$

At least two elements in the teachings of the Ioannites were obviously inspired by John of Kronstadt. The first was that "all evil in the modern world stems from Tolstoi and his followers." 59 The Ioannites interpreted the persecution they underwent in Russian society as a result of Tolstoi's pernicious influence. "Tolstoi has poisoned them [= contemporary Russians] with his lethal heresy. They are his worshippers, and through them Satan bellows to 
the world that we are swindlers. ${ }^{60}$ In addition, the Ioannites shared father John's conviction that Judgment Day was impending. The anti-Tolstoian, apocalyptic, and anticlerical currents in their thinking merged into one idea, as this quotation from one of their leaders shows:

O, antichrist (L.N.) Tolstoi, how long will you confuse, corrupt, and infect all pastors of the church, and through them lead their flock to eternal perdition? Lord, we pray to you and await your just Judgment, for life has become too hard. ${ }^{61}$

\section{The Solov'evian synthesis: Antichrist as a double}

The majority of those who regarded Tolstoi in an eschatological perspective were simple, uneducated people, but there were exceptions. One of the most original and profound Russian thinkers, Vladimir Solov'ev (1853-1900), saw the appearance of Tolstoianism as a sign that the world as we know it was coming to an end. This view he presented in his last major work, Three Conversations About War, Progress, And the End of History, to which also A Short Story Of Antichrist was appended. This work was published the year Solov'ev died, and has been hailed by some Russian Orthodox writers as one of the most eminent refutations of Tolstoianism ever written. ${ }^{62}$

Solov'ev had known Tolstoi personally and corresponded with him. Their relationship was always complicated, and quarrels alternated with reconciliations. In most respects, Solov'ev's spirituality was far removed from Tolstoi's. While Tolstoi was attracted to all that is simple and ethically practicable, Solov'ev was drawn toward speculation and mysticism. Throughout 
his adult life Solov'ev regarded himself as an Orthodox believer, but his skepticism toward the Russian church gradually increased. The paramount mission of the Christian church, as he saw it, is to infuse the world with the principles of love and freedom. Solov'ev elaborated a theory of what he called "the free theocracy," according to which the state must merge with the church in a higher synthesis, under the leadership of the latter. Orthodoxy, however, had withdrawn from the world and passively accepted a subservient position vis-à-vis the worldly powers. The Eastern churches had renounced any ambition of influencing society and were incapable of filling its soteriological mission. Instead, Solov'ev suggested, free theocracy could be implemented if the active and extrovert Catholic church joined forces with the powerful Russian Tsardom. This utopia he presented in the book Russia and the Universal Church, published in Paris in $1889 .^{63}$

Toward the end of his life, however, Solov'ev completely lost faith in his idea of a free theocracy and it is against this backdrop his last major work, Three Conversations, must be understood. In this book Solov'ev pronounced a harsh verdict over his own socio-religious vision, but, at the same time, also over Tolstoi. ${ }^{64}$ Modeled on Plato's dialogues, Three Conversations are structured as a symposium of five Russians vacating somewhere in the Mediterranean. The General is an old-fashioned man of honor and dignity, the Politician represents modern, Western ideas, while $Z$ is a Christian mystic. In the course of the conversation all three set out thoughts that Solov'ev himself could have subscribed to, but only the latter is his alter ego in a stricter sense. 
The only female member of the group is the Lady, whose philosophical position is somewhat hazy. The final participant, the Prince, professes religious anarchism and is the target of constant sardonic attacks from the others. The Prince never explicitly associates himself with any particular school of philosophy, but contemporary as well as modern commentators unfailingly identified him as a Tolstoian. ${ }^{65}$ Not only his message, but also his style is closely modeled on Tolstoi's didactic pamphlets.

Already in the first paragraph of the preface to Three Conversations Solov'ev formulates succinctly the theme to be discussed: "Is evil only a natural defect, an imperfection disappearing of itself with the growth of good, or is it a real power, possessing our world by means of temptations?" ${ }^{\prime 66}$ Earlier in his life Solov'ev had been inclined to agree with St. Augustine: evil has no substance. It is nothing but an absence of good, a privatio boni. ${ }^{67}$ By the time he wrote Three Conversations, however, Solov'ev's opinion had changed radically: Evil had become a real force. The General had fought in the Russo-Turkish war of 1877-78 and there is no doubt in his mind that evil, as manifested in the atrocities perpetrated by the Turks, had to be resisted by force of arms. In response, the Prince as a consistent pacifist argues that to take the life of another human being is unmitigated evil. Any person who commits manslaughter stoops to the level of the beasts. To be killed, on the other hand, can hardly be regarded as an evil at all: it is no worse than to die of cholera or pneumonia. Z immediately points out an inconsistency in the prince's teaching: according to his logic it is an unmitigated evil to commit an act that represents no evil to the victim. ${ }^{68}$ Solov'ev's most basic objection to Tolstoi's teaching is then put forward: Tolstoi does not accept the reality of evil. That is why Tolstoi believes in the possibility of establishing the Kingdom of God on earth. 
This objection, however, was devastating not only for Tolstoianism but also Solov'ev's own former idea of a free theocracy. This Solov'ev was fully aware of. He therefore concludes that all reveries about an earthly Kingdom of God are equally objectionable. Deep down they are not only utopian, but anti-Christian.

In Three Conversations the discussion now turns to the issues of war and progress. In the Politician's view, war is not an Absolute Evil, but as mankind progresses towards an ever more perfect society, it will wither away like an atrophied organ. Instead of God and war we will get culture and peace. $\mathrm{Z}$ does not disagree with this prognosis, but adds that he regards such progress as a symptom, a symptom of the end.

POLITICIAN. ... The end of what, I ask you?

Mr. Z. Naturally, the end of what we have been talking about. As you remember, we have been discussing the history of mankind, and that historical "process" which has doubtless been going on at an ever-increasing rate, and which I am certain is nearing its end.

LADY. C'est la fin du monde, n'est-ce pas? The argument is becoming a most extraordinary one!

GENERAL. At last we have got to the most interesting subject.

PRINCE. You will not, of course, forget Anti-Christ either.

Mr. Z. Certainly not. He takes the most prominent place in what I have to say. 
The Prince suddenly excuses himself and leaves. The others comment upon by his hasty departure: the lady suggests that the prince may have perceived Z's remarks as a personal attack, and asks whether one ought to consider him as the Antichrist incarnate. The General answers somewhat indeterminately.

Well, not personally, not he personally; it will be a long time before he gets as far as that. But he is on that track, all the same. As it is said in the Gospel of St. John: "You have heard, my little ones, that Anti-Christ is coming, and there are many Anti-Christs now." So one of these "many....."

The book has suddenly taken a surprising turn: while the prince initially was accused of denying the reality of evil, he is now presented as a servant of The Evil One. When the prince after a short while rejoins the company, he is given a rough ride by $\mathrm{Z}$ : the "lord" that the prince wants to serve, insists that men shall do good, but he does not manifest his own goodness in any acts of love himself. Until the opposite has been proven, $\mathrm{Z}$ will therefore assume that the prince's "lord" is not identical with the Christian God, but with the lord of this world, meaning the devil.

What prompted Solov'ev—alias Z—-to pass such a drastic verdict on the Prince, and by implication on Tolstoi? It was not the clearly and unambiguously anti-Orthodox aspects of Tolstoi's teaching that led him to this conclusion. Open enmity toward the Christian faith is nothing to be afraid of, Solov'ev believed. Each honest opponent of the Truth may at any time be turned into a new St. Paul. Zealous Christians like the Prince, however, were an entirely 
different matter. Their stance reminded $\mathrm{Z}$ of Judas the betrayer. ${ }^{69}$ Their teaching is more than just false religion: it is deception.

It is the aspects of Tolstoianism that too closely model true religion that in Z's eyes make it particularly sinister. $\mathrm{Z}$ admits that it took him a long while to see through it and determine its anti-Christian essence. Moreover, there is no doubt in his mind that the Prince is convinced that he is serving God when he is actually doing the devil's work. But we should not forget that the lord of this world is a wily gentleman who hides himself behind a mask of goodness. ${ }^{70}$

These ideas Solov'ev developed further in his Short Story About Antichrist that completes Three Conversations. Antichrist is presented as a remarkable man who stands forth in the $21^{\text {st }}$ century. At the age of thirty-three he is already hailed as a great thinker, writer, and social reformer. He is loved and respected, unselfish, and constantly active as a philanthropist. He lives the life of an ascetic, and is swayed neither by base passions nor by the sweet lure of power. In contrast to most people at the time this person is a convinced idealist. He believes in both Goodness and God. This is what he believes in, but he loves only himself. Initially, he recognizes the messianic dignity and significance of Christ, but gradually he turns against Him as he wants to be God's only chosen representative on earth himself. In a fit of rage he yells, foaming at the mouth: "He has not risen!" Now he tumbles like a ripe fruit into the net of the devil, who chooses him as his only begotten son, Antichrist. Antichrist's first act after his initiation is to write a book called The Open Way to the Universal Peace and Well-being that brings him world fame and he is elected President of the United States of Europe. In the end, the last pope suddenly realizes the true identity of Antichrist and excommunicates him. 
Antichrist is killed in a battle against the Jews and Christ returns in the skies to rule on earth for a thousand years.

Solov'ev's Antichrist is not identical either with Tolstoi or the Prince, and this is explicitly pointed out in the book itself. ${ }^{71}$ These three are nevertheless intimately related. On several specific points Tolstoi has clearly served as a model for the devil's latter-day representative in Solov'ev's conception. ${ }^{72}$ Like Antichrist, Tolstoi won his fame as a great thinker, writer, and social reformer. He was a religious idealist and a believer in God and Goodness. Antichrist's immunity to the temptations of the flesh and worldly power may be read as an allusion to Tolstoi's asceticism and anarchism. Finally, and most importantly, they both change the message of Christ into its exact opposite in such a subtle way that even experienced observers may be deceived. As Paul Valliere has remarked, in the story about the Antichrist Solov'ev shows how "the father of lies can subvert any ideal, even the most sublime. This is a crucial point in the polemic against Tolstoyanism."

Solov'ev's fictional analysis of Tolstoi's religious teaching found resonance among the RussianOrthodox radical right. Most explicitly we see this in Sergei Il'menskii's pamphlet More Clearly Than Most, Count L. Tolstoi Expressed The Spirit Of The Impending Antichrist, published in Saratov in 1911. Il'menskii's claimed that it was becoming increasingly difficult for Christians to distinguish between true and false preachers since even the worst enemies of God now hid behind purity and invoked the name of Christ. This, in Il'menskii's opinion, was a true sign of the End. There existed a widespread, but nevertheless quite erroneous notion of Antichrist as some kind of a grisly beast with flaming eyes. Such ideas were simply ludicrous. 
Il'menskii pointed out that in Three Conversations Solov'ev had disclosed the true nature of

Christ's ultimate opponent: he would march forth under the banner of philanthropy. Moreover, Solov'ev had also shown us who was carrying the banner for him.

Of all the precursors of the imminent antichrist Count Tolstoi, in our view, is the most horrible and seductive. Under the cover of personal goodness he manages to draw even the chosen ones, at the end of the world, into the gaping abyss of evil. ${ }^{74}$

Tolstoi had preached individual moral perfection, chastity, spiritual heroism, and service to society. He had stood forth as a preacher of goodness, and bolstered his message with references to the Gospel. His relationship to Christian truth, however, was purely external since he did not recognize the divinity of Christ. Tolstoi's aspiration to establish a new, rationalist religion, Il'menskii asserted, clearly demonstrated his anti-Christ-ian arrogance. ${ }^{75}$

All of this reminds us of the last antichrist, who, as the word of God and church tradition tell us, will insist on being treated with godly honors. He will proclaim himself as the benefactor of all mankind, and speak lofty and exalted words about some universal, unifying religion based on earthly reason. He will throw a shining covering of goodness and truth over the mystery of extreme lawlessness.

To Il'menskii it was precisely this shining coating of goodness and truth that set Tolstoi apart from the multitude of ordinary blasphemers and gave him anti-Christian dimensions. 
Identical reflections are found in the diary of archimandrite Arsenii (Zadinovskii). According to this monastic, Tolstoi had been a godless one in the full and true meaning of the word. But how then can we explain that he had constantly been talking about God, the Gospel, love, and other Christian principles? The key to this mystery could be found in the Scripture: Christ Himself had prophesized that the deceivers would be clad not in their own garments, but would hide their iniquity behind the Truth. In Matthew 24,5 Jesus had foretold that "many will come in my name, saying 'I am the Christ,' and they will lead many astray." This, Arsenii believed, was a precise prophesy of Tolstoi.

Did not Tolstoi come in the name of Christ, call himself a Christian, expound the Gospel and allegedly preach about Christ? Did he not seduce many? Antichrist himself, according to the faith of the church, will make use of exactly this method of enticement. Initially, he will captivate people by means of Christian principles, later he will openly rise up against Christ. ${ }^{76}$

The Orthodox literature on Tolstoi is vast and variegated. Many Russian theologians and laypeople concentrated on a particular aspect of Tolstoianism or one of Tolstoi's many tracts and articles, and scrupulously refuted them point by point, showing how and where his teaching deviated from Orthodoxy. Parts of this apologetics consisted of quite solid and erudite works but their dry style attracted few readers. Other anti-Tolstoian authors however, treated Tolstoianism in sweeping and bombastic terms. It is these writings that have concerend 
us in this article. These polemicists were less concerned with nuances and distinctions, and tended towards extreme, eye-catching characterizations such as 'Tolstoi, the antichrist'.

The identification of Tolstoi as Antichrist or with anti-Christian powers reflects, of course, a deep conviction that Tolstoi was an irreconcilable adversary of Christ. By itself, however, this view, however strongly held, would hardly suffice to cast him in as sinister a role. At the turn of the 19th century Russia was teeming with militant atheists and blasphemers whom no one would dream of associating with this most hideous persona of the Apocalypse. But Tolstoi differed crucially from these other enemies of the church on one decisive point: he hid his rebellion against God behind a mask of goodness and godliness, as Solov'ev's expressed it. The heretic of Iasnaia Poliana, it was believed, presented a counterfeit version of true religion that bore an uncanny resemblance to the real thing.

The Russian religious philosopher Vasilii Rozanov once remarked that each Christian church gets the heretics it deserves. By this he meant that a common trait of sectarians is their propensity to amplify out of all proportions certain ideas that are typical of the particular denomination from which they hail. In this way Rozanov explained the asceticism and selfmortification of the khlysty and skoptsy: these Russian sects magnified ab absurdum the lifedenying tendency that in Rozanov's view was latently present in Orthodoxy itself., ${ }^{, 77}$ Other historians of ideas have used similar arguments to explain aspects of the philosophy of for instance Friedrich Nietzsche and Emmanuel Lévinas: According to Alf Ahlberg and Karl Jaspers, Nietzsche's militant atheism was informed and motivated by his deep immersion into Protestant thought, while Jacques Derrida has maintained that Lévinas “is very close to Hegel, 
much closer than he admits, and at the very moment when he is apparently opposed to Hegel in the most radical fashion." 78

This line of reasoning may, mutatis mutandis, be used to understand also the relationship of Tolstoi to the Orthodox church. Despite their mutual intense dislike and the denunciations they hurled at each other both parties often recognized a distorted picture of himself in the other. Tolstoi was certainly not an Orthodox Christian. He broke decisively with the Orthodox, Christian faith on fundamental, crucial points, but this did not prevent him from copying —or "stealing" as his Russian detractors would say—from the Orthodox tradition in which he had been raised as a child. In fact, he himself indirectly acknowledges as much on several occasions. Thus, for instance, while he in Reply to the Synod described Orthodoxy as an undiluted "lie," in Confession, his very first religious-philosophical tract after his break with the church in 1884, he claimed that "Orthodoxy is truth and falsehood woven together with the finest threads."79 Therefore, it was his task, he explained, to untangle the true threads in the tapestry from the false ones. Similar mixed assessment of Orthodoxy may be found also in some of Tolstoi's other post-conversion writings. ${ }^{80}$

A similar ambivalent attitude was expressed by many men of the Orthodox church. In his book on Tolstoi and the Church (1939) archimandrite Ioann (Shakhovskoi), the future Russian Orthodox archbishop of San Francisco, used a biological metaphor to capture the essence of Tolstoianism that is remarkably similar to Tolstoi's tapestry metaphor. 
In his truth there is some falsehood and in his falsehood there is some truth. His religious falsehood is braided with his religious truth like a liana around a tree's trunk and sucks the tree dry. Like an ivy the Christian truth twines itself around the dead tree of Tolstoian ideas and gives this tree an appearance of blossom. ${ }^{81}$

As one will notice, the Tolstoian and Orthodox elements in this metaphor change places in the course of the quotation. The archimandrite, it seems, had difficulty making up his mind as to what exactly he should regard as the true core of Tolstoi's teaching and what in his view was the parasitic element.

\footnotetext{
${ }^{1}$ See Pål Kolstø, “A Mass for a Heretic? The Controversy over Leo Tolstoi’s Burial,” Slavic Review 60, vol. 1 (Spring 2000), 75-95.

${ }^{2}$ Father Fedor Preobrazhenskii, Uchenie L.N. Tolstogo o smysle zhizni po sudu khristianstva (Moscow, 1898), 1.

${ }^{3}$ Erwin Oberländer, Tolstoi und die revolutionäre Bewegung (Munich, 1965); Peter Ulf Møller, Efterspil til Kreutzersonaten: Tolstoi og kønsmoraldebatten i russisk litteratur $i$ 1890erne (Copenhagen, 1983).

${ }^{4}$ All told some 260 articles and at least 85 books and booklets on Tolstoi were published by professed Orthodox authors. See Pål Kolstø, Sannhet i løgn. Lev Tolstoj og den ortodokse tro (Oslo, 1997), 321-434.

${ }^{5}$ Møller includes Orthodox contributions to the Kreutzer Sonata debate in an annotated chronological appendix to his book, but for the most part ignores them in the main body of the text. Møller. Efterspil, 344-362.
} 
${ }^{6}$ John Shelton Curtiss, Church and state in Russia: the last years of the empire 1900-1917 (New York, 1940); Nicolas Zernov, The Russian religious renaissance of the twentieth century (London, 1963); A.A. Bogolepov, Church Reforms in Russia 1905-1918, (Bridgeport, Con., 1966). See also V. Pravdin, 'Reaktsionno li pravoslavie?', Tserkovno-obshchestvennyi vestnik, 1912, no. 22, Nov., 1-4.

${ }^{7}$ Antonii (Khrapovitskii), Besedy o pravoslavnom ponimanii zhizni i ego prevoskhodstvo nad ucheniem L. N. Tolstogo (St.Pb., 1889). Quoted from the reprint edition Zhizneopisanie i tvoreniia blazhenneishago Antoniia, Mitropolita Kievskago i Galitskago v 17 tomakh (New York, 1978), vol. XIV: 62-113, on 69; Sergei Bulgakov, "L.N. Tolstoi," in O religii Tolstogo. Sbornik statei (Paris, 1978), 1-26, on 12. Reprint of the Moscow 1912 edition. (The expression goes to $\mathrm{Gal} 3,24$.)

${ }^{8}$ Aleksandr Nikol'skii, "Lev Tolstoi i russkaia intelligentsiia v eia pogone za kumirami," Missionerskii sbornik, 1912, no. 4: 302-317, on 316.

${ }^{9}$ Amicus, “Otkrytiia pis'ma k drugu intelligentu uvlekaiushchemusia ucheniem L.N. Tolstogo," Missionerskoe obozrenie, 1899, no. 1: 72-81, on 73.

${ }^{10}$ I. Dmitrevskii, "Lichnost' grafa Tolstogo i prichiny ego vliianiia na obshchestvo," Vera $i$ razum, 1912, no.11: 627-639, on 627.

${ }^{11}$ Ivan IV, Peter the Great, and Napoleon were all interpreted as Antichrist by Russian believers. In the last decades before the 1917 Revolution the number of Antichrist identifications in Russia seems to have increased. Such different individuals as Nicholas II, Kaiser Wilhelm and Grigorii Rasputin were all cast in this role. See Pavel Miliukov, Ocherki po istorii russkoi kultury (Petrograd, 1909-1916), vol. 2, 48-54 -16; Vladimir BonchBruevich, "Voina i sektanty," Sovremennyi mir, 1914, December, 102-115.

12 “Opredelenie Sv. Sinoda ot 20-22 fevralia 1901 goda, s poslaniem vernym chadam Pravoslavnyia Grekorossiiskiia Tserkvi o grafa L've Nikolaeviche Tolstom,” Tserkovnye vedomosti, 1901, no. 8: 46-48.

${ }^{13}$ L. N.Tolstoi, Polnoe sobranie sochinenii v 90 tomakh (Moscow, 1930-72), vol. 34, 247. 
${ }^{14}$ Pål Kolstø, "Leo Tolstoy, A Church Critic Influenced by Orthodox Thought,"in Geoffrey Hosking, ed., Church, Nation and State in Russia and Ukraine (London, 1991), 148-166.

${ }^{15}$ Anders Nygren wrote about the self-evident presuppositions that are shared by all participants in a discourse in a certain epoch. See Anders Nygren, Filosofi och motivforskning (Stockholm, 1940), 67ff. Nygren's concept of self-evident presuppositions, I believe, may be applied not only to chronologically but also to spatially delimited cultures. Expressed in kuhnian terminology: the disagreements between Tolstoi and the Russian Orthodox theologians were strong and real, but contained within a common paradigm. See Thomas S. Kuhn, The structure of scientific revolutions (Chicago, 1962).

${ }^{16}$ Charles Lock, "Review of Richard F. Gustafson, Leo Tolstoy: Resident and Stranger," St. Vladimir's Theological Quarterly, 1987, 175-181, on 180.

${ }^{17}$ Some critics feel that Richard Gustafson in his major work Leo Tolstoy. Resident and Stranger (Princeton, 1986) goes too far in this direction. See e.g. Lillian J. Helle, “Tolstoj’s Resurrection and Orthodox Rhetoric," in Translating Culture: Essays in Honour of Erik Egeberg, eds, Geir Kjetsaa, Lennart Lönngren and Gunnar Opeide (Oslo, 2001), 116.

${ }^{18}$ The Petersburg clergy are generally regarded as the most liberal in Russia. See e.g. Gregory Freeeze, The Parish Clergy in Nineteenth-Century Russia (Princeton, 1983), 470-72.

${ }^{19}$ Including Mikhail Tareev, Konstantin Aggeev, Stefan Kozubovskii, and N. Drozdov.

${ }^{20}$ Father Stefan Ostroumov, "Religioznoe i nravstvennoe uchenie L.N. Tolstogo v ikh polozhitel'nom znachenii," in Otdykh khristianina, 1916, no. 1:116-130, ibid. 1916, no. 2 : 118-122, ibid. 1916, no. 3: 178-193, ibid. 1916, no. 5-6: 131-155, ibid. 1916, no. 7-8,: 211218, and ibid. 1916, no. 10: 152-165.

${ }^{21}$ Ostroumov, "Religioznoe i nravstvennoe uchenie," 1916, no. 1:116.

${ }^{22}$ In the first decades of the $20^{\text {th }}$ century the St.Petersburg Religio-Philosophical society was an important meeting place for liberal clergy and religiously minded intelligentsia. See Jutta Scherrer, Die Petersburger religiös-philosophischen Vereinigungen (Berlin, 1973).

${ }^{23}$ Kolstø, “A mass for a heretic?," 70-80. 
${ }^{24}$ Vasilii Ekzempliarskii, “Gr. L.N. Tolstoi i sv. Ioann Zlatoust v ikh vzgliade na zhiznennoe znachenie zapovedei Khristovykh,” O religii Tolstogo, 76-113, on 109.

${ }^{25}$ Ibid., 79.

${ }^{26}$ Vasilii Ekzempliarskii, Za chto menia osudili? (Kiev, 1912), 10.

${ }^{27}$ Sergei Bulgakov, “Samozashchita V.I. Ekzempliarskago,” Russkaia mysl', 1912, no. 8: 39_ 40.

${ }^{28}$ Antonii, Besedy o pravoslavnom ponimanii zhizni, 69.

${ }^{29}$ Antonii (Khrapovitskii), "V chem prodolzhalo otrazhat'sia vliianie pravoslaviia na posledniia proizvedeniia gr. L.N. Tolstogo." Quoted from Zhizneopisanie i tvoreniia, vol. XIV: 247-268.

${ }^{30}$ Ibid., 256.

${ }^{31}$ Ostroumov, "Religioznoe i nravstvennoe uchenie", 1916, no. 5-6: 148.

${ }^{32}$ Antonii (Khrapovitskii), Besedy o prevoskhodstve pravoslavnago ponimaniia Evangeliia sravnitel'no s ucheniem L. Tolstago (St.Pb., 1891).

${ }^{33}$ Bishop Antonii's assessment of Tolstoianism was in many ways so similar to Petrov's and Ekzempliarskii's positions that one may wonder why the two latter priests were censured while Antonii was not. (On the contrary, his career continued to rise, and at the Russian Church Council of 1917 he was only one step away from being elected Russian patriarch.) One possible reason might be that Antonii was simply better connected, but perhaps most importantly, while Petrov and Ekzempliarskii used Tolstoi as a whip with which to lash out against social injustice in Russia, Antonii's criticism was directed against the lax moral standards of his fellow Orthodox Christians only.

${ }^{34}$ Ivan Aivazov, ”Kto takoi L.N. Tolstoi? (Po povodu postanovleniia Moskovskoi gorodskoi dumy chestvovat' 80-letie Tolstogo)," Tserkovnye vedomosti, 1908, no 34, appendix: 16221628, on 1624.

${ }^{35}$ Father Ioann Vostorgov, Znameniia vremen (Moscow, 1909), 1.

${ }^{36}$ Cfr. Revelation, 13, 2. Iz dnevnika o. Ioanna Kronshtadtskago, 26.; and See e.g. N.

Griniakin, “Utverdi, Gospodi, tserkov'!” (St.Pb., 1904), 552 and 565. 
${ }^{37}$ Ioann (Kronshtadtskii), 'Otvet o. Ioanna Kronshtadtskago na obrashchenie gr. L.N. Tolstogo k dukhovenstvu', in Prisnopamiatnyi Otets Ioann Kronshtadtskii i Lev Tolstoi (Jordanville, 1960), 15. See also Revelations 13, 2.

${ }^{38}$ For instance, P. Kraniev, "Otpevanie" grafa L.N. Tolstogo s evangel'skoi i tserkovnoi tochki zreniia. (Po povodu sovremennoi gazetnoi shumikhi (Riazan', 1913), 15 and 20; Aleksandr Bronzov, "Drug ili vrag Khristov-Tolstoi?" Khristianskoe chtenie, 1912, no. 4: 463-482, on $480 \mathrm{ff}$.

${ }^{39}$ In German, der Antichrist may refer to both the eschatological persona and to each and every opponent of Christendom. Friedrich Nietzsche plays upon this duality in the title of his book Der Antichrist.

${ }^{40}$ Mikhail Sopots'ko, ”Po povodu iubileia 'grafa L.N. Tolstogo'," Student-khristianin, 1908, no.11-12: 29-30, 29.

${ }^{41}$ What the New Testament says on the subject of the Antichrist is extremely fragmentary. He is mentioned only in the first and second letters of St. John, partly in the singular, partly in the plural. In 1 John 2,18-19 the apostle explains: "Little children, it is the last time, and as ye have heard that antichrist shall come, even now there are many antichrists, whereby we know that it is the last time. They went out from us, but they were not of us."

In 1 John 2,22 Antichrist is further defined as the one who denies that Jesus is the Christ. In 2 John he is referred to as a deceiver, "who confess[es] not that Jesus Christ is come in the flesh." It is clear from the context that antichrist is in league with the Devil himself and acts as his representative in the last time.

In Christian apocalyptic writings the picture of the Antichrist has been filled in with details taken from other books of the Bible. The Book of Daniel tells about a dreadful beast at the end of time. It has ten horns plus an eleventh, small one that comes up among them. The little horn has eyes like a man and a mouth speaking great things. Traditionally this horn has been identified with the antichrist, as has "the Wicked one" describied in St. Paul's second 
letter to the Thessalonians, and the second beast of the Revelation. This beast performs great miracles and all that dwell upon the earth worship it. His number is $666(\operatorname{Rev} 13,11-18)$.

${ }^{42}$ Ernest I. Simmons, Leo Tolstoy (London, 1949), 532. See also Aylmer Maude, The Life of Tolstoy (Oxford, 1987), vol. 2, 308.

${ }^{43}$ See e.g. Mitr. Muretov, "Khristianin bez Khrista," Dushepoleznoe chtenie, 1893, no. 3:370385.

${ }^{44}$ Dushepoleznoe chtenie, 1899 , no. 5: 142-148. Such numerology had a long pedigree in Russian apocalyptic speculations. See e.g. W.F. Ryan, "Magic and Divination: Old Russian Sources", in Bernice Glatzer Rosenthal, ed., The Occult in Russian and Soviet culture (Ithaca N.Y., 1997), 35-58.

${ }^{45}$ Even if one should be inclined to accept this line of reasoning it is not self-evident why the patronymic also had to go. This middle name is, after all, given to a person to signify not that he is a spiritual son of the church, but to tell who his worldly father is. The anonymous reader, moreover, allowed himself also certain other liberties in order to be able to arrive at his conclusion. These were based on an oral, phonetic rendering of Tolstoi's patronymic rather than the correct orthographic spelling, which would have been Nikolaevich.

${ }^{46}$ Dushepoleznoe chtenie, 1899, no. 5: 142ff, and Dushepoleznoe chtenie, 1901, no. 9: 143.

${ }^{47}$ Dushepoleznoe chtenie, 1901, no. 9: 338.

${ }^{48}$ Dushepoleznoe chtenie, 1901, no. 9: 143ff. The same calculation was later reprinted in another anti-Tolstoian Orthodox publication, The Complete Unmasking of the Heretic on Iasnaia Poliana. See A. Golubtsev and I. Alekseev, Polnoe razoblachenie iasnopolianskogo eretika (St.Pb., 1909).

${ }^{49}$ See e.g. Dushepoleznoe chtenie, 1901, no.7: 488.

${ }^{50}$ Nadieszda Kizenko, A Prodigal Saint: Father John of Kronstadt and the Russian People (University Park, 2000), 244. 
${ }^{51}$ Ioann (Kronshtadtskii), Iz dnevnika o. Ioanna Kronshtadtskago v oblichenie lzheucheniia grafa L.Tolstogo. Izdanie V.M. Skvortsova (St.Pb, 1907); Ioann (Kronshtadtskii), Otvet o. Ioanna Kronshtadtskago.

${ }^{52}$ Ioann, Iz dnevnika, 47.

${ }^{53}$ Quoted in Dushepoleznoe chtenie, 1901, no. 7, 488.

${ }^{54}$ Ioann, Iz dnevnika, 6.

${ }^{55}$ See James 2, 19.

${ }^{56}$ Ioann $I z$ dnevnika, 34. See also Kizenko, A Prodigal Saint, 257-59.

${ }^{57}$ Dmitrii Bogoliubov, “O tak nazyvaemykh ‘ioannitakh’ v russkom narode,” Otdykh khristianina, 1909, no: 2; 121-131, on 126; Grigorii Vechernii, Ioannity (St.Pb., no year given), 19.

${ }^{58}$ J. Eugene Clay, “Orthodox Missionaries and 'Orthodox Heretics' in Russia, 1886-1917”, in Rober P. Geraci and Michael Khodorkovsky, eds. Of Religion and Empire: Missions, Conversion, and Tolerance in Tsarist Russia, (Ithaca:, 2001), 55. N. Sokolov, "Prokliatie ‘ioannitov’ o. Ioannom Kronshtadskim,” Vera i razum, 1908 no. 16, 527-530.

${ }^{59}$ Quoted in Vechernii, Ioannity, 22.

${ }^{60}$ Pravda o sekte ioannitov (St.Pb., 1906).

${ }^{61}$ N. Bol'shakov, as quoted in Bogoliubov, “O tak nazyvaemykh,” 123.

${ }^{62}$ Se e.g. Aleksandr Nikol'skii, "L.N. Tolstoi pred sudom pokoinago filosofa Vl. S.

Solov'eva," Missionerskii sbornik, 1910, no. 2: 109-118, on 110.

${ }^{63}$ Vladimir Solov'ev, "Rossia i Vselenskaia Tserkov"” in $O$ khristianskom edinstve (Brussels, 1967), 249-383.

${ }^{64}$ Peter Normann Waage, Der unsichtbare Kontinent: Wladimir Solowjow, der Denker Europas (Stuttgart, 1988).

${ }^{65}$ See e.g. Evgenii Trubetskoi, "Spor Tolstogo i Solov'eva o gosudarstve”, O religii Tolstogo, 62: James H. Billington, The Icon and the Axe: An Interpretive History of Russian Culture (New York, 1970), 469 and 492; Judith Deutsch Kornblatt, "Soloviev on Salvation: 
The Story of the 'Short Story of the Antichrist"', in Judith Deutsch Kornblatt and Richard F. Gustafson, eds, Russian Religious Thought (Madison, Wisc., 1996), 68-87.

${ }^{66}$ Vladimir Solov'ev, “Tri razgovora,," Sobranie sochinenii (St.Pb. 1903), vol. 8: 453-586,

453. Here and in other quotations below I follow Alexander Bakshy's translation in War,

Progress, and the End of History (London, 1915). Emphasis in the original.

${ }^{67}$ Konstantin Mochul'skii, Vladimir Solov'ev. Zhizn i uchenie (Paris, 1951), 250.

${ }^{68}$ Solov'ev, "Tri razgovora,", 470ff.

${ }^{69}$ Solov'ev, "Tri razgovora,", 553.

${ }^{70}$ Solov'ev, “Tri razgovora,”, 553.

${ }^{71}$ Solov'ev, "Tri razgovora,", 554.

${ }^{72}$ Mochul'skii, Vladimir Solov'ev, 259.

${ }^{73}$ Paul Valliere, Modern Russian Theology: Bukharev, Soloviev, Bulgakov. Orthodox Theology in a new Key (Grand Rapids, Mich., 2000), 221.

${ }^{74}$ Sergei Il'menskii, Graf L. Tolstoi kak odin iz samykh iarkikh vyrazitelei dukha griadushchiago antikhrista (Saratov, 1911), 1.

${ }^{75}$ As a young man Tolstoi wrote about such an aspiration in an isolated note in his diary in 1855 but never returned to it (see Tolstoi, Polnoe sobranie, vol. 47: 37-38.) He would most likely been highly surprised if anyone had suggested to him that his religious teachings after 1884 sprang out of the same aspiration.

${ }^{76}$ Arsenii (Zadinovskii), Graf Tolstoi i nashe neverie (Moscow, 1911), 74.

${ }^{77}$ Vasilii Rozanov, Temnyi lik. Metafizika khristianstva (Würzburg, 1975, reprint of the St.Pb., 1911 edition), especially 99-127.

${ }^{78}$ Alf Ahlberg, Friedrich Nietzsche-hans liv och verk (Stockholm, 1923), 111, and Karl Jaspers, Nietzsche og kristendommen (Oslo, 1977), 58. Nietzsche himself applied this kind of reasoning when he declared that "the protestant pastor is the grandfather of German philosophy.” Friedrich Nietzsche, “der Antichrist,” Werke I-V (Munich, 1979), vol. 3; 1171 : 
Jacques Derrida, Writing and Difference (London, 1978), 99, quoted in Iver B. Neumann, Uses of the other: "the East" in European identity formation (Minneapolis, 1999), 230.

${ }^{79}$ Tolstoi, Polnoe sobranie sochinenii, vol. 23, 53.

${ }^{80}$ Kolstø, Sannhet i løgn.

${ }^{81}$ Archimandrite Ioann (Shakhovskoi), Tolstoi i tserkov' (Berlin, 1939), 101. 